\title{
ERP IMPLEMENTATION EFFECT ON INTERNAL CONTROL OF CORPORATE BANKING IN INDONESIA STOCK EXCHANGE LISTING IN 2014-2016
}

\author{
Inabhimantra Ageng*, Soewarno Noorlailie, Isnalita \\ Faculty of Economics and Business, University of Airlangga, Indonesia \\ *E-mail: agenginabhimantra@gmail.com
}

\begin{abstract}
Enterprise Resource Planning (ERP) is a single data entry system that provides many benefits for the company, one of them an increase in internal controls. This study aims to determine the factors that affect the internal control of companies using ERP implementation variables as independent while the size of the company and leverage as control variables. The samples used were banking companies listed in Indonesia Stock Exchange in 20142016. The results showed that ERP implementation has no effect on the company's internal control, while the size of the company's control variables showed significant results.
\end{abstract}

\section{KEY WORDS}

Control system, firm size, leverage, internal control, business.

This study discusses the implementation of Enterprise Resource Planning (ERP) of the company's internal controls in financial reporting aspects. ERP is defined as an information system that integrates all business processes and business units within a company by using a single data entry (Hamilton, 2002). This study used a sample of the banking company has a complete data and listing on the Indonesia Stock Exchange from 2014 until 2016. The selection is done by the banking company banking sector companies have more risk (eight primary risk) compared to companies in other sectors. Events in Indonesia several years ago experienced the Century Bank as a failed bank with systemic impact and provide information that internal control is important. Azhar Maksum (2005) states that there are still many companies in Indonesia which although already gone public, assume that the internal controls as part of good corporate governance as an accessory and not just the basic needs of the company. Research on companies of this sector is still rare in Indonesia that are expected to contribute to the development of similar research. 2014 to 2016 have been selected as relevant to the years covered by the study. More consistent results of the research into the expectations of researchers to increase the number of samples to three years.

Sarbanes Oxley Act (2002) requires companies to report on the effectiveness of internal controls in the financial statements as part of the overall effort to prevent and reduce fraud in the financial reporting process. Internal control is one way that companies use to reduce agency costs (Jensen and Payne, 2003). Abdel-Khalik (1993) and Barefield et al (1993) proved that a high internal control can reduce agency cost. Research carried out by Doyle et al (2006) explains that a weak internal control indicate earnings management behavior are higher. Deumes and Knechel (2008) found that conscious companies to report internal control reports though when there are no requirements as required by the Sarbanes Oxley Act. Good internal controls can improve the performance of the company in an effort to achieve good corporate governance. The importance of internal controls responded to the company one of them with the ERP implementation.

ERP implementation in Indonesia in recent years has increased significantly. Companies with complexity and high business risks tend to take precaution by implementing ERP as their information systems. ERP is claimed able to simplify business processes so that the company's internal control will increase. In addition, the ERP also provides advantages by providing data in real time and easy access. This will impact on the speed and accuracy of decisions. 
This study tested that a company's internal control related to the ERP implementation, the size of the company and leverage. Internal control is measured by the natural logarithm of the frequency number of meetings held by the audit committee within one year. ERP implementations in companies measured using dummy variables to give a score of 1 on the companies that have been implemented and a score of 0 for no. Company size measured by the natural logarithm of total assets and leverage is calculated by dividing total debt by total assets. Researchers divided the ERP implementation as independent variables, firm size and leverage as control variables and internal control as the dependent variable.

The sample in this study a number of 111 banking companies during the three-year period 2014 to 2016. Data were obtained from the official website of Indonesia Stock Exchange and the company's website. In this study, researchers only focused on companies that consistently publish annual report and the financial report as well as the discount data completeness. Companies that do not have the completeness of the data will be removed from the population.

The results of this study contributes to the literature and is something that is important so that it can be used as a discussion by the various parties, especially related to ERP and internal control. ERP implementation is thought to enhance the company's internal control. On the other hand, the adoption of this system accommodates the misinformation that is no longer confined to one area of the company but will be disseminated throughout the company's business environment (Lynn and Madison, 2000). The high costs in the implementation of this system must be properly considered and reviewed by the company to deliver its intended results.

\section{LITERATURE REVIEW}

Agency Theory. Birth of agency theory motivated by a wide range of theories about the relationship of the difference of interests, one of which the theory of the game (game theory). Scott (2014) states that to understand what is in the interests of management in its financial reporting duties, it is necessary to consider a theory called the theory of games (game theory). Game theory is an approach used to define the circumstances in various interests (Von Neumann and Morgenstern, 2007). Game theory explains how a decision is taken by using analyzes involving several different from a rational approach. In this condition occurs dependencies between various interests and needs solving problems as possible.

Game theory helps to know how the interested parties (stakeholders) the company agreed to take a decision with a variety of consequences (Arifah, 2012). This theory explains the best decision can be taken in the condition in which a wide variety of different interests.

Agency theory is when one of the parties concerned to act as an agent, working for someone, representatives, while others act as a major part of the problem (Ross, 1973). Agency theory is a condition in which one party called the principal using the services of another party, called the agent in order to commit an act or work for the principal purpose. The problem that sometimes occurs in these conditions is any divergence of interest between principal and agent so that the expected results are not the same as the objectives agreed upon at the beginning.

Management as the party that controls the company has more information than the owners. As a consequence, ERP implementation is done in the hope the owners are able to provide the information they want and less of actions or things done by management that hurt the company, one of which earnings management.ERP implementations also provide benefits in terms of improving the company's internal control. Internal control is a good company will encourage companies to achieve good corporate governance.

Signalling Theory. Signalling theory explains how the company provides a signal to the users of financial statements with information about what has been done policy management for the benefit of the owner. ERP implementation is a signal that the company that will better internal controls. Signal theory can be used to avoid information asymmetry with respect to the implementation of Good Corporate Governance. Signal theory benefit the company 
regarding the implementation of good corporate governance is better so as to create a good corporate quality (Subramaniam et al., 2009).

Asymmetry of information is a condition where a party obtaining information by an amount more than the other parties. This resulted in the incompatibility decision, causing a risk for the company. Investors, creditors and external parties are basically using information provided by management to make a good decision-making investment and financing decisions. Therefore, the quality of information provided by the company plays an important role to determine the company's future. One of the signal to improve the quality of information is to establish a committee which signifies that the company is better in terms of supervision.

Impact of ERP as part of the internal control. Powers and procedures is an important aspect and not in spite of the company's internal control system. Therefore, the necessary division of authority within the company related to its operations. The division of authority is done with the hope that the decision is obtained quickly and accurately so that the activities of the company can be run properly and will eventually have an impact on the increase in value of the company. Indra Bastian (2002) explains that it should be made a system that regulates the distribution of power to provide otoriasasi implementation of each transaction in the organization.

The ERP system is an information system package that integrates information and information based processes within and outside the functional areas of an organization. Integration means that the system incorporates data from the various divisions of the company for later use division to share data and communicate with each other.ERP also provides benefits for the company to present the data in realtime. When companies want a quick in taking decisions, the ERP is present as one of the solutions.

Some research on ERP and internal controls have been carried out and the results were mixed. Morris (2011) Explains that after the directives issued by SOX, companies that implement ERP showed a rise in the improvement of internal control. The increase was reflected in internal control over at least the internal control weaknesses disclosed when the company has implemented ERP. While Doyle (2006) revealed that many factors that are determinant internal control. Specific aspects owned company into something unique so that the selection control procedures should be adjusted, not limited by the ERP implementation.

Hypothesis. The development of this hypothesis will be explained as follows:

ERP system is a package that integrates information systems and information-based process information from within and outside the functional areas in aorganization. The integration in this case is to combine all the information sourced from the company's divisions are then collected and used together for interested parties. ERP change the traditional communication systems company, where the traditional system, the design of the system is fragmented and each system is designed as a solution for specific operational issues rather than as part of an overall corporate strategy (Hall, 2002). ERP is also used to control all of the company's resources. In addition, ERP systems help generate management information that is real time and used to make decisions that affect the survival of the company.

Morris (2011) stated that based on the decision of SOX, companies that have been implemented ERP proven to improve internal controls, compared with companies that do the implementation. Improved internal controls visible from fewer reports of internal control weaknesses reported by the companies that have implemented ERP.

H1: Implementation Enterprise Resource Planning (ERP) effect on the company's internal control.

The size of the company is one of the important factors that affect the internal control (Chen et al., 2009). Large companies would have the potential to be difficult to implement the monitoring because it has a larger agency problems (Jensen and Meckling, 1976).

Large-sized companies are expected to take action assessment and risk control more effectively. The surveillance was in line with management responsibility to the stakeholders associated with the ownership of the company bigger and broader. Management should be such as creating and implementing internal controls in order to reduce the various risks 
inherent in the company. Risk to be borne by the company with the larger sizes such as financial risk, reputation, operational, regulatory and risk information (KPMG, 2001).

H2: Firm size effect on the company's internal control.

Companies that have a number of major long-term debt on the liabilities would have a greater financial risk (Goodwin and Kent, 2006). Jensen and Meckling (1976) in Purbawati (2011) stated that it needed more monitoring costs when the company's leverage ratio is high. This is because the transfer of wealth from lenders who tend to be high thus increasing the agency cost (Chen et al., 2009). Companies with high leverage are required to run the system of corporate governance including good internal control.

H3: Leverage effect on the company's internal control.

Conceptual Framework. The conceptual framework of this research is as follows:

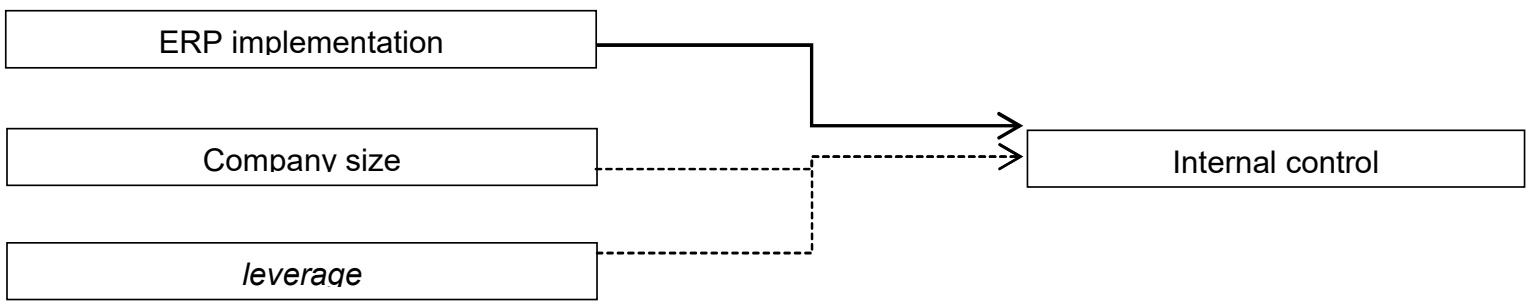

\section{METHODS OF RESEARCH}

Population and Sample. The population in this study is banking sector companies listed on the Indonesia Stock Exchange from 2014 until 2016. Sampling using purposive sampling with criteria published financial statements and annual reports as well as a complete display data for research purposes.

Variables, Operational Definitions and Technical Analysis. The independent variable in this research is the implementation of ERP, measured by a dummy variable, a score of 1 for companies that have ERP and 0 for no. Using a control variable firm size measured by the natural logarithm of total assets and leverage is calculated by dividing total debt by total assets. While the dependent variable is the internal control and measured by the natural logarithm of the number of meetings held by the audit committee within one year.

This study using multiple linear regression analysis to determine the effect of the implementation of Enterprise Resource Planning (ERP) of the company's internal control. Multiple linear regression model in this study are as follows:

$$
I C=a+\beta 1 E R P+\beta 2 \text { Size }+\beta 3 \text { Lev }+e
$$

Where: IC - Internal control; a - constants; $\beta$ - The regression coefficient; ERP - ERP implementation; Size - company size; Lev - leverage; e - error.

\section{RESULTS AND DISCUSSION}

General overview of the subject of research. The subjects were banking companies listed in Indonesia Stock Exchange from 2014 until 2016. The number of samples obtained by purposive sampling is as follows:

Table 1 - Criteria for sampling

\begin{tabular}{|c|c|c|}
\hline No. & Criteria & amount \\
\hline 1. & $\begin{array}{l}\text { Banking companies listed in Indonesia Stock Exchange } \\
2014 \text { to } 2016\end{array}$ & 129 \\
\hline 2. & Banking companies that do not have complete data & (18) \\
\hline & Number of samples & 111 \\
\hline
\end{tabular}

Source: Secondary data is processed. 
Description of the research results:

Table 2 - Descriptive statistics

\begin{tabular}{llllll}
\hline & $\mathrm{N}$ & Min & Max & mean & Std. deviation \\
\hline ERP & 111 & .00 & $1: 00$ & .86 & .343 \\
Size & 111 & 27.34 & 34.58 & 30.91 & $18: 25$ \\
Leverage & 111 & .74 & .95 & .85 & .46 \\
Internal Control & 111 & .69 & 3.61 & $2: 24$ & .64 \\
Valid N (listwise) & 111 & & & & \\
\hline
\end{tabular}

Source: Output SPSS version 21.0 (secondary data processed).

Based on the results of descriptive statistics above, the company with the largest size is Bank Mandiri while the company with the smallest size is Bank Artos Indonesia. Then, the company with the highest leverage level is the Bank Pembangunan Daerah Banten and the lowest is Bank Dinar Indonesia. Finally, the company with the highest level of internal control is of BRI Agroniaga while the lowest is the Bank Artos Indonesia.

Analysis of models and hypothesis testing:

Table 3 - Normality test

\begin{tabular}{ll}
\hline Model & unstandardized residuals \\
\hline $\mathrm{N}$ & 111 \\
Kolmogorov-SmirnovZ & .916 \\
Asymp. Sig (2-tailed) & .372 \\
\hline
\end{tabular}

Source: Output SPSS version 21.0 (secondary data processed).

Based on the above normality test, obtained significance value of 0.372 . This value is greater than 0.05 , which means that the research data are normally distributed.

Table 4- Heteroscedasticity test

\begin{tabular}{|c|c|c|c|c|c|}
\hline \multirow[t]{2}{*}{ Model } & \multicolumn{2}{|c|}{ unstandardized coefficients } & \multirow{2}{*}{$\begin{array}{l}\text { standardized coeff., } \\
\text { beta }\end{array}$} & \multirow[t]{2}{*}{$t$} & \multirow[t]{2}{*}{ Sig. } \\
\hline & $B$ & Std. error & & & \\
\hline (Constant) & 26816 & 73360 & & .366 & .715 \\
\hline ERP & 17060 & 9378 & .182 & 1,819 & .072 \\
\hline Size & -.016 & .018 & -.089 & -.886 & .378 \\
\hline Lev & .576 & .663 & .083 & .868 & .387 \\
\hline
\end{tabular}

Source: Output SPSS version 21.0 (secondary data processed).

Based on the above output obtained significance value of ERP variables for 0072 , 0378 and lev size by 0387 . The third significant value has a value of more than 0.05 . Thus it can be said that there is no heteroscedasticity.

Table 5 - Multicollinearity test

\begin{tabular}{lllll}
\hline Model & $\mathrm{t}$ & Sig. & $\begin{array}{l}\text { collinearity } \\
\text { tolerance }\end{array}$ & $\begin{array}{l}\text { Statistics } \\
\text { VIF }\end{array}$ \\
\hline (Constant) & -2928 & .004 & & \\
ERP & -.258 & .797 & .899 & 1,112 \\
Size & 6813 & .000 & .902 & 1,109 \\
Lev & -.372 & .711 & .978 & 1,023 \\
\hline
\end{tabular}

Source: Output SPSS version 21.0 (secondary data processed).

Based on the above output is known that variable has a value of VIF 1,112 ERP, size has a value of 1,109 and 1,023 lev. If the VIF value smaller than 10 can be concluded that there is no multicollinearity. Thus, it was concluded that there is no multicollinearity in this study. 
Table 6 - Autocorrelation test

\begin{tabular}{llllll}
\hline Model & $\mathrm{R}$ & $\mathrm{R}$ square & Adj R square & Std. Error of the estimate & Durbin-Watson \\
\hline 1 & .565 & .319 & .300 & 54075 & 1,851 \\
\hline
\end{tabular}

Source: Output SPSS version 21.0 (secondary data processed).

Based on the above output obtained Durbin-Watson value of 1.851. Then the DurbinWatson table for $\mathrm{N}=111$ and $\mathrm{K}=3$ is the value of the upper limit of 1,746 . $1851 \mathrm{dw}$ value more than the upper limit value (du) 1746 and less than (4-du) by 2253 so it was concluded that no autocorrelation.

Table 7 - Multiple Linear Regression Test

\begin{tabular}{llll}
\hline Variables & Regression Coefficients & $\mathrm{t}$ & significance \\
\hline Constant & -362747 & -2.928 & .004 \\
ERP & -4090 & -.258 & .797 \\
Size &, 203 & 6813 & .000 \\
Leverage & -.417 & -.372 & .711 \\
\hline F count = 16 696 & significance 0000 & R square = 0565 & \\
\hline
\end{tabular}

Source: Output SPSS version 21.0 (secondary data processed).

Determinant coefficient ( $R$ square) statistical test results in this study show the number 0.565 . This suggests that the independent variables and control variables in research (ERP, company size and leverage) is able to explain the dependent variable (internal controls) of 0565 or $56 \%$. While the rest is explained by other variables outside the research model.

Regression model formed from this test are as follows:

$$
\text { IC }=-362747-4.090 \mathrm{ERP}+0.203 \text { Size }-0.417 \mathrm{Lev}+\mathrm{e}
$$

Based on the results of the partial test (t test) on a significance value of each independent variable and variable control of the dependent variable. ERP implementation independent variables showed significant value of 0.797 whose value is greater than the level of significance in the study of $5 \%(0: 05)$. This means that statistically, ERP implementation in the banking company did not significantly affect internal controls. As for the control variables firm size showed significant gains against the internal control and leverage variables showed no significant results.

Then for simultaneous testing (test $f$ ) obtained significance value of 0.000 . This value is below the significance level of $5 \%$ of research which means that simultaneous, ERP implementation, the size of the company and leverage effect on the company's internal control.

This study rejects the hypothesis $(\mathrm{H} 1)$ who stated that the implementation of ERP effect on the company's internal control. The results of this study contrast with a study conducted by Morris (2011) which states that companies that have implemented ERP fewer reported internal control weaknesses. In addition, the results of this study are also not supported by Carlos et al (2013) which states that companies investing ERP benefit by the availability of internal information that can be used to improve internal controls.

On the other hand, the results of this study are consistent with a study conducted by Doyle (2006) stated that many factors affect the company's internal control. Hassabelnaby (2012) in his research concluded that ERP implementation does not significantly influence the capability of the company includes variable operating capability as part of the internal control procedures. The survey conducted by Deloitte on 64 companies in the Fortune 500 states that as many as 25 percent of companies that have made a failed ERP implementation of internal controls over setelag implementation period (Hall and Singleton, 2007). Their rationale and specific conditions in the enterprise requires the company to face the different internal control risk. ERP implementation is not necessarily able to improve internal controls on certain types of company. Brown (2005) states that kompentesi users 
play an important role in a system. High competence enables a well-managed system. A good system but is not supported by the knowledge, skills, motivation and readiness user will result in something that is not optimal.

Top management support in the period before and after the implementation process is a very important thing (Plant and Willcocks, 2007). Management must be able to convince all the elements within the organization to switch from a manual system to the systembetter through ERP. ERP implementation will change the company's business system so that the required resources are qualified in terms of the operation. This system should be supported by the commitment of employees ranging from top level to the bottom level.

Factor Training is also a matter of concern. The training provides an understanding of the user about what the duties and responsibilities of each. Hall and Singleton (2007) stated that training costs can be higher than the cost of implementing the system of having to learn a new procedure that is often forgotten in the budgeting process. The composition of the team members in the implementation of ERP is also worth considering. Companies that perform ERP implementation must impose the responsibility of all parties, not just at one particular division. Supriyadi (2005) states that the ERP will provide a close link between departments so that it takes coordination.

ERP implementation is not solely dependent on the quality of the systems and technologies that exist in the system. Not an increase in the company's internal control is one proof that there are other factors that influence factors. Companies sometimes to ascribe the failure of ERP implementation in the improvement of internal control is purely due to the ERP system itself. Whereas, in the implementation process is a very important thing to consider.

Furthermore, to test the variable size of the company is to receivetwo hypotheses $(\mathrm{H} 2)$ which states that the size of the company's influence on the company's internal control. These results are consistent with research conducted by Andarini (2010), which conducts research on the company go public in Indonesia. Companies with a large size will be more focus on good corporate governance than companies with smaller size. The major asset owned also encourage companies to manage risk through increased internal control so as to optimize the performance of the company. Great company is also a benchmark and spotlight stakeholders so that a good internal control are considered capable of providing added value in the eyes of the public company.

Otherwise the results obtained for testing variables leverage, This study rejects the hypothesis of three $(\mathrm{H} 3)$ which stated that the leverage effect on the company's internal control. The leverage ratio measures the extent to which the debt that the company can generate an asset for the company's survival. Jensen and Meckling (1976) in Purbawati (2011) states that it takes a greater monitoring costs when the company's leverage ratio is high. Companies with relatively high debt will reduce the activities that are considered unnecessary and are not optimal (Chen, et al in Andarini 2010). Companies with relatively high debt would take a decision to consider more things and tend to be more cautious because of their cost.

\section{CONCLUSION}

This study examined the effect of ERP implementation of the internal control of the company. The sample used is a banking company listing The Indonesia Stock Exchange from 2014 until 2016, with the number of 111 companies. Based on the hypothesis testing, the result that the ERP implementation in the banking company does not affect the internal controls. While testing of the control variables obtained results that affect the size of the company's internal control, while leverage has no effect.

This study has several limitations. Future studies are expected to increase and expand the sample is not limited to the company's banking sector to find out the results of research carried out on the object when a wider and different. Future studies are also expected to increase the number of years of observation in order to obtain better results and maximum. 


\section{REFERENCES}

1. Abdel-Creator, AR 1993. Why do private auditing companies demand? A case for organizational loss control. Journal of Accounting, Auditing and Finance 8: 31-52

2. Andarini, Princess of Revelation and Indira Januarti. 2010. Relationship characteristics and the Company's Board of Commissioners Against Disclosure of Risk Management Committee On Public Listed Companies Indonesia. Purwokerto: Accounting National Symposium XIII.

3. Arifah, DA 2012. At the Agency Theory Practice for Public and Non-Public Entities. Achievement, Vol 9, No 01.

4. Barefield, RM, JJ Gaver, and TB O'Keefe. 1993. Additional evidence on the economics of attest: Extending results from the audit market to the market for compilations and reviews. Auditing: A Journal of Practice \& Theory 12 Spring: 74-87.

5. Brown, William and Frank Nasuti. 2005. What ERP systems can tell us about SarbanesOxley. Information Management \& Computer Security Vol 13: 311-327.

6. Carlos Alberto Dorantes, Chan Li, Gary F, Vernon J. 2013. The effect of enterprise systems implementation firm information on the environment. Contemporary accounting research Vol 30: 1427-1461.

7. Chen, L., Kilgore, A., and Radich, R. 2009. Audit committees: the voluntary formation by non-top ASX 500 Managerial Auditing Journal, 24 (5), 475-493.

8. Bastian, Indra and Billy Soepriyanto. 2002. The public sector accounting system. Jakarta: Salemba four.

9. Deumes, R., and WR Knechel. 2008. Economic incentives for voluntary reporting on internal risk management and control systems. Auditing: A Journal of Practice \& Theory 27, 1: 35-66.

10. Doyle, JT, W. Ge, and S. McVay. 2006. Determinants of weaknesses in internal control over financial reporting. Journal of Accounting and Economics 44 1-2: 193-223.

11. Goodwin, J and Kent. 2006. The use of internal audit by Australian companies. Managerial Auditing Journal, Vol. 21 No. 1, 81-101.

12. Hall, AJ 2002. Accounting Information Systems (Translation), Issue 2. Jakarta: Four Salemba.

13. Hamilton, S. 2002. Maximizing your ERP system a Practical Guide Manager. McgrawHill.

14. Hassabelnaby, 2012. The Impact of ERP Implementation on Organizational Capabilities and Firm Performanace. The International Journal Vol 19, 2012.

15. Jensen, KL, and JL Payne. 2003. Management of trade-offs of internal control and external auditor expertise. Auditing: A Journal of Practice \& Theory 22, 2: 99-119.

16. Jensen, MC and Meckling, WH 1976. Theory of the firm: Managerial behavior, agency costs and ownership structure. Journal of financial economics, 3 (4), 305-360.

17. KPMG, U. 2001. Understanding Enterprise Risk Management: An Emerging Model for Building Shareholder Value: White Paper of KPMG's Assurance and Advisory Services Center. Available from http: // www. kpmg. com.

18. Morris, John J. 2011. The impact of ERP systems on the effectiveness of internal controls over financial reporting. Journal of information system 25 (1): 129-157

19. Lynn M, Madison R. 2000. The role of ERP software revisited. Journal of Accountancy. 190 (1): 104-105.

20. Infallible, Azhar. 2005. Review of the GCG in Indonesia. Speech at the inaugural permanent professorship in the field of management accounting at the Faculty of Economics USU.

21. Plant, Robert and Willcocks, Leslie. 2007. Critical Success Factor in International ERP Implementations: A Case Research Approach. Journal of Computer Information Systems.

22. Purbawati, Dinalestari. 2011. Effect of commissioners characteristics, characteristics of the company, and the existence of a risk management committee on voluntary disclosure. Thesis Accounting. Semarang: Diponegoro University. 
23. Ross, SA 1973. The economic theory of agency: The principal's problem. The American Economic Review, 134-139.

24. Scott, WR 2014. Financial accounting theory. Canada: Pearson Education.

25. Subramaniam, N., McManus, L., and Zhang, J., 2009. Corporate governance, firm characteristics and risk management committee formation in Australian companies. Managerial Auditing Journal, 24 (4), 316-339.

26. Supriyadi. 2005. Information Technology and Business Functions.

27. Von Neumann, J. and Morgenstern, O. 2007. Theory of games and economic behavior: Princeton University Press. 